\title{
Etnoarqueologia e processo de territorialização entre os indígenas Wasusu do vale do Rio Guaporé, estado de Mato Grosso, Brasil
}

\author{
Ethnoarchaeology and territorialization process between \\ the Wasusu indigenous of the valley of Rio Guaporé, state \\ of Mato Grosso, Brazil
}

Rafael Lemos de Souza ${ }^{1}$

Jorge Eremites de Oliveira ${ }^{2}$

DOI: http://dx.doi.org/ 10.20435/tellus.v19i39.582

\begin{abstract}
Resumo: Neste artigo os autores analisam criticamente o processo de territorialização vivenciado pelos indígenas Wasusu, um dos povos Nambikwara do vale do Rio Guaporé, no estado brasileiro de Mato Grosso, a partir da segunda metade do século XX. Até os anos 1950, a maior parte da região era quase que exclusivamente habitada por coletivos Nambikwara, cuja população total foi estimada em aproximadamente 20.000 indivíduos. Da década de 1950 à de 1980, terras indígenas foram expropriadas no contexto de uma política oficial destinada ao desenvolvimento econômico do estado e da região brasileira da Amazônia Legal. Esta política teve o objetivo de beneficiar empresas colonizadoras e agentes das elites locais, e foi implementada por meio da apropriação ilegal do território de vários povos nativos, como é o caso dos Wasusu.
\end{abstract}

Palavras-chave: Etnoarqueologia; História Indígena; indígenas Wasusu; processo de territorialização; Vale do Rio Guaporé.

\begin{abstract}
In this article the authors critically analyze the process of territorialization experienced by the Wasusu Indians, one of the Nambikwara peoples of the Guaporé River Valley, in the Brazilian state of Mato Grosso, from the second half of the $20^{\text {th }}$ century. Until the 1950s, most of the region was almost exclusively inhabited by Nambikwara collectives, whose total population was estimated at approximately 20,000 individuals. From the 1950 s to the 1980s, indigenous lands were expropriated in the context of an official policy aimed at the economic development of the state and the Brazilian region of
\end{abstract}

1 Universidade Federal do Rio de Janeiro (UFRJ), Rio de Janeiro, Rio de Janeiro, Brasil.

2 Universidade Federal de Pelotas (UFPel), Pelotas, Rio Grande do Sul, Brasil. 
the Amazônia Legal (Legal Amazon). This policy had the purpose of benefiting colonizing companies and agents from the local elites and was implemented through the illegal appropriation of the territory of several native peoples, as is the case of Wasusu.

Keywords: Ethnoarchaeology; Indigenous History; Wasusu indians; process of territorialization; Valley of the Guaporé River.

\section{INTRODUÇÃO}

O presente artigo resulta, em grande parte, de pesquisas realizadas para fins de conclusão de uma dissertação de mestrado em antropologia, cujos estudos são de natureza etnológica, arqueológica e histórica sobre parte de um território indígena localizado no estado de Mato Grosso, área tradicionalmente ocupada pelos Wasusu (SOUZA, 2014)³. Acrescenta-se ainda experiências e dados de outra pesquisa, realizada para fins de avaliação dos impactos socioambientais de um empreendimento minerador sobre a comunidade Katitaurlu, também conhecida como Nambikwara do Sararé (EREMITES DE OLIVEIRA e PEREIRA, 2009).

Para a realização do trabalho de mestrado, buscou-se compreender elementos da cultura material, sistema de assentamentos, subsistência e processo de territorialização do povo indígena Wasusu (Nambikwara) no alto curso do rio Guaporé. Não obstante ao assunto, registra-se que a análise aqui apresentada tem o propósito de analisar criticamente a expropriação das terras indígenas regularizadas ou em processo de regularização no vale do rio Guaporé. Esta situação histórica é verificada ao longo do século XX, no contexto de uma política oficial voltada ao desenvolvimento econômico da região compreendida pelo sudoeste de Mato Grosso e o sul de Rondônia, na Amazônia Legal, sobretudo no âmbito da expansão de frentes econômicas ligadas a atividades agropecuárias.

A maior parte da pesquisa de campo que embasa empiricamente este trabaIho foi realizada durante três etapas de campo, perfazendo 34 dias de etnografia, nas aldeias Anunsu, Bacurizal, Central, Pedreira e Rio Novo. Para a coleta in loco de dados, a metodologia aplicada é a tributária do arcabouço teórico-metodológico da

\footnotetext{
3 Ao longo deste trabalho, o termo antropologia é empregado no sentido de antropologia social ou cultural ou sociocultural, conforme utilizado no Brasil, e não, necessariamente, no sentido dos quatro campos clássicos da antropologia geral de matriz boasiana, assim institucionalizada nos Estados Unidos e outros países das Américas.
} 
antropologia, notadamente o método etnográfico - neste trabalho mais percebido como processo e menos como produto -, o qual também é recorrido na prática etnoarqueológica (EREMITES DE OLIVEIRA, 2011, 2015a, 2015b). Este procedimento de registro de dados etnográficos se caracteriza pela realização de trabalho de campo, no qual se faz necessário, dentre outras estratégias, "[...] entrevistar informantes; observar rituais; deduzir os termos de parentesco; traçar as linhas de propriedade; fazer o censo doméstico [...] escrever seu diário" (GEERTZ, 1989, p. 7). Outra característica do método é a observação participante. Trata-se de estar no lugar que se está a investigar, na perspectiva de buscar fazer parte da vida cotidiana dos indivíduos com os quais se interage. O propósito é participar de suas atividades, tanto às de caráter simbólico (rituais religiosos, por exemplo) como às de cunho material (caçadas, pescarias, produção de artefatos etc.), observando-as atentamente a partir do que se quer compreender a respeito de seu modo de vida e da materialidade a ela subjacente. Esta é uma forma pela qual pode ser levado a cabo, com maior competência, o trabalho etnográfico a que se dedica o pesquisador, como explica Malinowski (1978, 1984), seja ele etnólogo, seja etnoarqueólogo.

A observação participante, caracterizada pela observação direta dos acontecimentos e da vida cotidiana, não se confunde, como observado por Eremites de Oliveira e Pereira (2010), com o conceito de descrição densa a que Geertz faz menção em A interpretação das culturas (GEERTZ, 1989). Portanto, a observação realizada sobre os Wasusu não se confunde com descrição densa pelo fato de que tal abordagem metodológica exigiria maior tempo de pesquisa em campo, inclusive o domínio da língua nativa. Entretanto, importa esclarecer que o trabaIho ora apresentado tampouco se trata de uma etnografia a jato, como explica Ribeiro (2010) para casos de estudos em curtíssimo tempo.

Acredita-se que as diretrizes apontadas por Geertz (1989) e Malinowski $(1978,1984)$ não se realizam sem o que Cardoso de Oliveira (2006) assevera ser o trabalho do antropólogo: olhar, ouvir e escrever. Desse modo, o estudo realizado junto aos Wasusu somente foi possível graças ao emprego desses procedimentos de pesquisa, sem os quais não se saberia como proceder ou se orientar em campo. Os dois primeiros atributos foram os mais utilizados in loco, onde o papel do pesquisador é o de olhar e ouvir, sentidos que para Cardoso de Oliveira são os primeiros a serem acionados pelo pesquisador. Isso ocorre porque o objeto que se olha já foi previamente modificado pelo nosso próprio modo de enxergar: "No ato de ouvir 
o 'informante' [interlocutor], o etnólogo exerce um poder extraordinário sobre o mesmo, ainda que pretenda posicionar-se como observador o mais neutro possível, como pretende o objetivismo mais radical" (CARDOSO DE OLIVEIRA, 2006, p. 23).

A segunda etapa é marcada pelo ato de escrever, isto é, de interpretar teoricamente os dados obtidos em campo. Seria, por assim dizer, o trabalho de gabinete. Desse modo, a dificuldade que se impõe ao etnólogo e ao etnoarqueólogo nessa etapa dos estudos, dentre tantas outras impingidas ao pesquisador, situa-se entre o "estar lá" e o "estar aqui" (GEERTZ, 2005). Este duplo movimento, onde o interstício é marcado pela liminaridade, em que não se está nem "lá" e nem "cá", é o que faculta à antropologia, enquanto ciência do social, a sua própria existência ontológica no tocante a ser um campo do conhecimento científico. O mesmo entendimento é válido para a etnoarqueologia, especialidade da arqueologia voltada à observação e compreensão da materialidade das relações sociais no tempo e espaço, especialmente dedicada a povos e comunidades não ocidentais.

Geertz (2005), em Obras e vidas: o antropólogo como autor, problematiza as questões referentes à prática etnográfica como um trabalho que ocorre mediado pelos dois momentos relacionados à sua produção: o "estar lá" e o "estar aqui", ou seja, a inter-relação entre o espaço e o tempo da pesquisa de campo e o espaço e o tempo das esferas acadêmicas. Examinados o olhar, o ouvir e o escrever, a que conclusões podemos chegar? - indaga Cardoso de Oliveira (2006). Como procura-se demonstrar aqui, essas "faculdades" do espírito têm características bem precisas quando exercitadas na órbita das ciências sociais e, de um modo todo especial, na da antropologia. Se o olhar e o ouvir constituem a percepção sobre a realidade focalizada na pesquisa empírica, o escrever passa a ser parte quase indissociável do pensamento, uma vez que o ato de escrever é simultâneo ao ato de pensar. Chama-se à atenção sobre o assunto de modo a tornar claro que é no processo de redação de um texto que o pensamento caminha. Isso é feito para se encontrar soluções a problemas que dificilmente apareceriam antes da textualização dos dados provenientes da observação sistemática (CARDOSO DE OLIVEIRA, 2006, p.31-32).

Ressalta-se ainda que as entrevistas feitas em campo não foram realizadas tendo um fim em si mesmas, isto é, não foram aplicadas sem a devida cautela que o referido método exige, posto que é consenso entre muitos cientistas sociais - das mais diversas formações e orientações teóricas e metodológicas - que tal procedimento científico não é infalível. Muitas entrevistas foram feitas com 
apoio de interlocutores bilíngues, os quais contribuíram decisivamente para a compreensão e tradução das falas de pessoas idosas, registradas na língua nativa, o idioma Nambikwara.

Os estudos também foram inspirados no que alguns autores chamam de antropologia e arqueologia do colonialismo. Para a prática de descolonização da pesquisa, valeu-se das experiências descolonizantes publicadas por Eremites de Oliveira (2011, 2015a, 2015b, 2016), Eremites de Oliveira e Pereira (2010), Silva (2000, 2009a, 2009b), Silva et al. (2011), González Ruibal (2006) e Stuchi (2010), dentre outros estudos etnoarqueólogos realizados especialmente no Brasil. Ao menos três pontos são fundamentais nessa prática de pesquisa socialmente engajada: primeiro, realizar estudos a partir de entendimentos prévios com a comunidade e de modo que o trabalho a ser feito atenda a seus interesses; segundo, dar visibilidade e voz ao coletivo que venha a ser estudado; terceiro, proceder de modo a relativizar a autoridade do etnoarqueólogo frente a outros conhecimentos, especialmente aos saberes nativos. Segundo Silva et al. (2011), dessa maneira as práticas arqueológicas se tornam mais inclusivas, menos colonizadoras e fazem com que o pesquisador melhor relativize o controle do conhecimento sobre o passado e diminua sua autoridade na interpretação e divulgação dos dados sobre o coletivo estudado.

Essas ideias vão ao encontro do pensamento de Silva et al. (2011, p.37) com relação à arqueologia colaborativa, no qual os autores a definem da seguinte maneira: "[...] prática arqueológica que visa estabelecer a colaboração e o envolvimento de diferentes coletivos nas questões relativas à pesquisa e gestão do patrimônio cultural". Seguindo este ponto de vista, a pesquisa colaborativa busca trazer um balanceamento nos interesses entre pesquisadores e as comunidades que possam vir a ser estudadas. Em estudos etnoarqueológicos mais recentes, realizados no Brasil e em outros países, as pesquisas tendem a ser colaborativas, haja vista o emprego da observação direta ou participante como procedimento metodológico. Por isso, conforme ainda pontuam os autores, os termos estratégicos e metodológicos podem ser definidos como: interação entre equipe de pesquisa e comunidade; presença da equipe durante todo o trabalho; busca de recursos para a comunidade; manter a comunidade ciente de como o trabalho está a ser feito; e acesso fácil da comunidade sobre os vestígios arqueológicos e outros dados da pesquisa. 
Informa-se que na pesquisa realizada junto aos Wasusu não houve nenhum tipo de escavação e coleta de material arqueológico. Ressalta-se a importância desta explicação, haja vista que populações tradicionais costumam ter uma relação muito intensa com a materialidade existente em seus territórios, como explicado por Eremites de Oliveira (2016) em relação aos cemitérios Kaiowá em Mato Grosso do Sul. Com relação à metodologia etnográfica recorrida em trabalhos etnoarqueológicos, alguns dos autores supracitados explicam que a comunicação e a colaboração com o coletivo estudado devem existir em todo processo da pesquisa (SILVA et al., 2011).

Cumpre ainda esclarecer que na área de estudo foram feitas entrevistas registradas em gravador digital e por meio de filmagens em vídeo. Foi utilizado aparelho GPS (Sistema de Posicionamento Global) para o georreferenciamento das aldeias, a fim de visualizar de maneira mais ampla as continuidades e as mudanças no que se refere aos padrões de uso do ambiente onde a comunidade está estabelecida: localização da aldeia na TI (Terra Indígena); dispersão das casas uma das outras; roças e cursos d'água; áreas de descarte de elementos materiais; etc. Para este trabalho também se vale dos registros etnográficos feitos nos diários de campo de Maria Aurora da Silva (2010), antropóloga e mãe de um dos autores que assinam este artigo, produzidos na época em que esteve com os Wasusu a trabalho ou apenas para visitar as comunidades.

Todos esses procedimentos técnicos, metodológicos e teóricos foram de grande relevância para a conclusão do estudo ora apresentado.

\section{OS NAMBIKWARA DO VALE DO GUAPORÉ E O PROCESSO DE TERRITORIALIZAÇÃO WASUSU}

Autores como Roquette-Pinto (1975 [1917]), Price (1972, 1976, 1989) e Miller (2007) explicam que o termo Nambikwara ( $n a m b i=$ orelha; kuara= furada), de origem Tupi, é um apelativo que surgiu durante o encontro colonial e passou a ser designado para categorizar um grande número de povos indígenas que habitam a porção oeste do estado de Mato Grosso até as adjacências no estado de Rondônia. Este grande território indígena, situado numa região de transição ou ecótono entre os biomas Amazônia e Cerrado, está dividido em três áreas geograficamente distintas: Serra do Norte, Chapada dos Parecis e Vale do Guaporé. 
De acordo com J. Miller, o vale do rio Guaporé:

[...] corresponde ao oeste do território Nambikwara, entre o limite do planalto acima mencionado e o rio Guaporé. Conforme a descrição de Price, $85 \%$ desta região é coberta por floresta. Na parte abaixo do planalto a floresta é mais densa e o solo mais fértil. A floresta diminui a oeste, na direção do rio Guaporé a área que é composta por várzeas e planícies inundáveis. Em direção ao rio Guaporé correm rios Cabixi, Piolho, Galera e Sararé (MILLER, 2007, p. 17).

Até os anos 1950, grande parte do Vale do Guaporé era quase que exclusivamente povoada pelos Nambikwara. Esta região, contudo, tem sido ocupada por populações indígenas desde há mais de 12.000 anos, segundo atestam os estudos de Miller (1983). Àquela época, os indígenas somavam cerca de 20.000 indivíduos, concentrados em um território que grosso modo distava do rio Guaporé aos rios Papagaio, Comemoração, Roosevelt e Tenente Marques ${ }^{4}$. Dispunham de um território de uns 5.500.000 hectares, situado entre os municípios de Vila Bela da Santíssima Trindade e Pontes e Lacerda, em Mato Grosso, e o de Vilhena, no estado de Rondônia (PRICE, 1972).

Do ponto de vista linguístico, Price (1972) classifica os Nambikwara como falantes de línguas pertencentes à família homônima de um tronco linguístico comum. Define-os como falantes de três línguas, cada uma com suas particularidades, mas reciprocamente inteligíveis. Quanto à localização geográfica, assevera que se encontram concentrados em três extensões distintas, pelo menos no que diz respeito às questões referentes ao habitat ou território: Vale do Guaporé, Campos do Vale do Guaporé e Norte do Vale do Guaporé.

No tempo presente, o território tradicionalmente ocupado por aproximadamente trinta povos Nambikwara encontram-se separado em nove terras indígenas descontínuas, quais sejam: Vale do Guaporé, Pirineus de Souza, Nambikwara, Lagoa dos Brincos, Taihãntesu, Pequizal, Sararé, Tirecatinga e Tubarão-Latundê. Esta última área está situada no estado de Rondônia e é habitada por um povo Nambikwara denominado Latundê e por outros coletivos indígenas denominados de Aikanã. Há ainda outras áreas em processo de regularização, como a Terra Indígena Paukalirajausu, contínua à Sararé.

4 De acordo com informações obtidas através do sítio online da FUNASA, atualmente os Nambikwara somam 1.950 indivíduos (FUNASA, 2010 [http://pib.socioambiental.org/pt/povo/ nambikwara]). 
Figura 1 - Localização da área de estudo, Terra Indígena Vale do Guaporé.

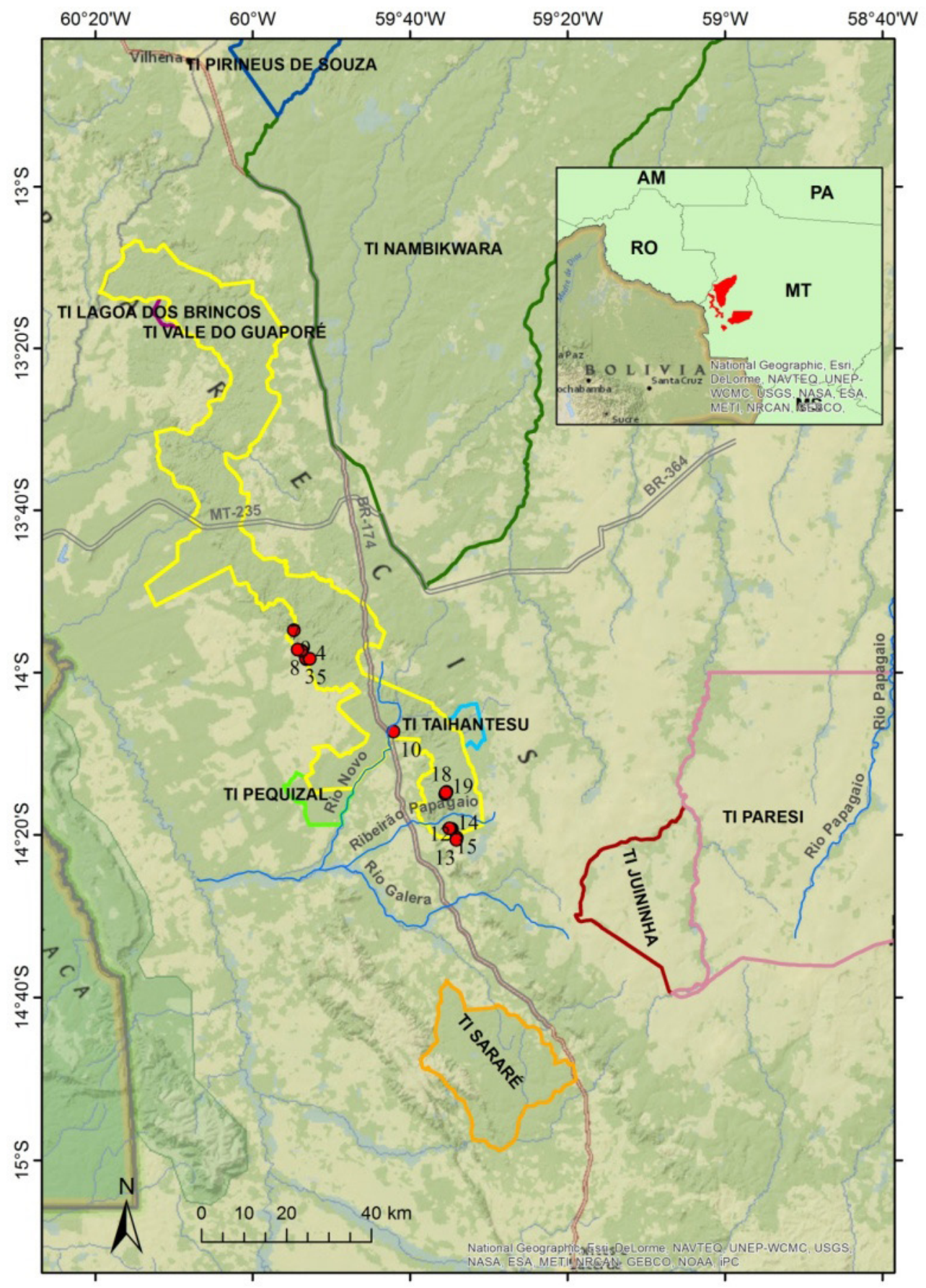

Fonte: Souza (2014, p. 22). 
Segundo Martins (2009), após a Segunda Guerra Mundial (1939-1945) o governo de Mato Grosso intensificou o processo de venda de terras indígenas não regularizadas no vale do rio Guaporé e em outras tantas partes do estado. Isso foi feito de modo a beneficiar pessoas e empresas colonizadoras que aspiravam se apoderar das terras indígenas localizadas nesta parte do Centro-Oeste do país. O território dos Wasusu, assim como o dos demais povos originários da região, foi ilegalmente disponibilizado pelo governo estadual para projetos de colonização e desenvolvimento. Ocorre que para as autoridades governamentais - representantes das elites locais e nacionais, as quais também estavam dentro das próprias instituições do Estado nacional -, aquela área era considerada um vazio demográfico improdutivo e abandonado. Neste contexto, deve-se entender que o órgão indigenista oficial, incialmente o SPI (Serviço de Proteção aos Índios), extinto em 1967, e posteriormente a Fundação Nacional do Índio (FUNAI), criada no ano seguinte, em 1968, durante o regime militar (1964-1985), teve a pretensão de tutelar os povos indígenas e inseri-los a uma ordem contrária a seus interesses (FERNANDES DA SILVA, 1987). Para a autora: "[...] a política indigenista sempre navegou ao sabor dos interesses da política econômica nacional e sempre se traduziu em pressões integracionistas as populações tribais" (FERNANDES DA SILVA, 1987, p.23). Diante da política de desenvolvimento oficial, adotada pelo estado de Mato Grosso, entende-se que a partir desse momento teve início um processo de territorialização, de acordo com o conceito formulado por Pacheco de Oliveira (1998):

[...] a noção de territorialização é definida como um processo de reorganização social que implica: 1) criação de uma nova unidade sociocultural mediante o estabelecimento de uma identidade étnica diferenciadora; 2 ) a constituição de mecanismos políticos especializados; 3 ) a redefinição do controle social sobre os recursos ambientais; 4) a reelaboração da cultura com o passado. O que estou chamando de processo de territorialização é justamente, o movimento pelo qual um objeto político-administrativo - nas colônias francesas seria a "etnia", na América espanhola as "reducciones" e "resguardos", no Brasil as "comunidades indígenas" - vem a se transformar em uma coletividade organizada, formulando uma identidade própria, instituindo mecanismos de tomada de decisão cultural e de representação, e reestruturando as suas formas culturais (inclusive as que o relacionariam como ambiente e com o universo religioso) (PACHECO DE OLIVEIRA, 1998, p.55-6). 
A ideia de processo de territorialização está associada à noção de situação histórica, quer dizer, de momentos ou períodos marcados por contatos interétnicos assimétricos, como aconteceu, por exemplo, com os Wasusu e outros povos Nambikwara em relação às frentes econômicas da sociedade nacional que se instalaram em seus territórios. Disso resultam tentativas de dominação e exploração, inclusive com mudanças no sistema de assentamento dos indígenas: se antes estavam estabelecidos numa determinada área, com nichos ecológicos favoráveis a atividades de caça, pesca, coleta, manejo agroflorestal e agricultura, a depender dos episódios de conflitos vivenciados, tiveram que mudar seus estabelecimentos para outros lugares. Esta mudança poder ser estudada a partir do que Eremites de Oliveira e Pereira (2010) chamam de etnoarqueologia do território.

Ainda de acordo com Martins (2009), milhões de hectares foram oferecidos a empresas colonizadoras para que elas mesmas efetuassem a compra das terras. De 1951 a 1955, vinte empresas receberam áreas com concessões para a colonização, sendo que todas tinham muitas afinidades com o governo do estado. Isso fazia com que o desempenho de suas empreitas tivesse bom resultado. Conforme informações apresentadas pelo referido autor, das vinte empresas que adquiriram posses nas áreas vendidas, apenas cinco cumpriram com as exigências mínimas estabelecidas em lei.

No governo de Pedro Pedrossian (1966-1971), o Departamento de Terras e Colonização do estado de Mato Grosso foi extinto. Esta decisão foi tomada para, dentre outras coisas, evitar a venda ou a concessão de terras para colonização por meio da iniciativa privada. Ocorre que em 1953, o loteamento de terras em Mato Grosso foi definido pela Lei n. 1.806; e em 1966, houve a criação da Superintendência do Desenvolvimento da Amazônia (SUDAM), órgão que tinha os seguintes objetivos:

Estabelecer uma política demográfica que compreende a regeneração física e social das populações da região, pela alimentação, assistência à saúde, o saneamento, a educação e o ensino, a imigração de correntes de população que mais convenham ao interesse da região e do país. Interessar o capital privado na exploração das riquezas regionais, inclusive em empreendimentos de capital misto (MARTINS, 2009, p. 2).

O referido autor complementa que em 1966, o objetivo do plano sofreu uma redefinição, porém os pontos básicos foram mantidos. Após dez anos, 5.400.000 
hectares da extensão de Mato Grosso estavam nas mãos de 199 grandes empreendimentos. Parte desta vasta área estava no sudoeste do estado, onde está localizado o território de vários povos indígenas falantes da língua Nambikwara, entre eles os Wasusu. Esses loteamentos geraram conflitos por parte de três grupos distintos: o de latifundiários, que na maioria dos casos inicialmente comprou terras para especulação de mercado; o de posseiros, que há algum tempo ocupavam pequenos pedaços de terra no território; e o de comunidades indígenas, que até a década de 1950 eram quase que exclusivamente os únicos ocupantes das terras.

É importante salientar que até certo momento havia uma convivência pacífica entre latifundiários e posseiros, pois os grandes capitalistas precisavam da mão-de-obra deles para a derrubada das florestas para formação de pastagens para bovinos. Como os posseiros tinham pouca terra e força política, e quase nenhum capital, dependiam de uma complementação financeira para o sustento de suas famílias. No entanto, quando as pastagens ficavam prontas, os latifundiários passaram a perceber um excesso de mão-de-obra e assim expulsaram os posseiros de suas terras (MARTINS, 2009). Esta situação é retratada por González Casanova (2002) para o contexto mais amplo da América Latina; esclarece que populações indígenas e pequenos lavradores (posseiros) só tinham conflito com grandes fazendeiros quando se tornavam mão-de-obra barata.

Em situações desse tipo, Pels (1997) argumenta sobre a importância de se estudar os colonos envolvidos nesses processos, visto que deixaram alguns "legados" mais duradouros na colonização, os quais são subprodutos de um colonialismo interno. Dentre os "legados" está a ideia preconceituosa de que os indígenas constituiriam um obstáculo ao progresso material capitalista, pois seriam avessos ao trabalho e suas terras seriam improdutivas. O autor continua a argumentação a inferir que as grandes plantações (monoculturas) e o emprego do trabalho forçado têm como raiz o colonialismo europeu, que forneceu para os não europeus a prática da escravidão. Este pensamento vai ao encontro do paradigma de colonialismo interno de que trata González Casanova:

Os povos, minorias ou nações colonizadas pelo Estado-nação sofrem condições semelhantes às que os caracterizam no colonialismo e no neocolonialismo em nível internacional: 1) habitam em um território sem governo próprio; 2) encontram-se em situação de desigualdade frente às elites das 
etnias dominantes e das classes que as integram; 3) sua administração e responsabilidade jurídico-política concernem às etnias dominantes, às burguesias e oligarquias do governo central ou aos aliados e subordinados do mesmo; 4) seus habitantes não participam dos mais altos cargos políticos e militares do governo central, salvo em condição de "assimilados"; 5) os direitos de seus habitantes, sua situação econômica, política social e cultural são regulados e impostos pelo governo central; 6) em geral os colonizados no interior de um Estado-nação pertencem a uma "raça" distinta da que domina o governo nacional e que é considerada "inferior", ou ao cabo convertida em um símbolo "libertador" que forma parte da demagogia estatal; 7) a maioria dos colonizados pertence a uma cultura distinta e não fala a língua "nacional" (GONZÁLEZ CASANOVA, 2007, p. 432).

Nota-se, portanto, que a partir da segunda metade do século XX, os Wasusu e outros povos Nambikwara estabelecidos no vale do rio Guaporé passaram a intensificar os contatos interétnicos com representantes as frentes econômicas da sociedade nacional. Tiveram seu território titulado a favor de terceiros, o que se deu por parte do governo de Mato Grosso, e os desdobramentos desse processo estão ligados ao que se considera como um colonialismo interno. Disso resulta uma situação histórica particular e um processo de territorialização em áreas a eles destinadas pelo Estado brasileiro, onde comunidades inteiras foram confinadas e tiveram que se adaptar a outro tipo de vida.

\section{PROCESSO DE REGULARIZAÇÃO DE TERRAS INDÍGENAS NO VALE DO GUAPORÉ}

O processo de regularização de terras indígenas no Vale do Guaporé, incluindo a terra homônima, teve início nas décadas de 1960 e 1970. Price (1989), em seu livro Before the Buldozer, relata como se deu o processo de identificação e delimitação de reservas indígenas para os Nambikwara no período. O autor informa que em 1968, o general Artur da Costa e Silva, presidente do Brasil nos tempos do regime militar (1964-1985), deferiu a criação da Reserva Nambikwara, área dividida pelos rios Juína e Camararé.

De acordo com relatório da FUNAl:

A exploração do território Nambikwara, por empresas agropecuárias e madeireiras, trouxe aos índios a desestruturação de seu ecossistema, redução de seus recursos de fauna e flora, poluição de fontes de água, destruição de 
roças por rebanhos, contagio de doenças, subnutrição, redução populacional, e comprometimento de sua própria sobrevivência (FUNAI, 1981, p. 18).

Price (1989) informa que a área demarcada, cerca de 1/6 do território e originalmente ocupada por uma pequena parte da população Nambikwara, era, quase que totalmente, formada por terra improdutiva onde a pobreza e a aridez do solo eram patentes. Pretendia-se, por parte do governo federal, assentar na área todos os povos Nambikwara que habitavam a região e circunvizinhanças. A pretensão do Estado brasileiro era liberar as demais áreas, geralmente com solo mais produtivo, a empreendimentos privados de natureza agropastoril.

No relatório citado anteriormente (FUNAI, 1981, p.19), é colocado que no dia 8 de outubro de 1968, através do Decreto n. 6.368, foi criada a Reserva Indígena Nambikwara. Havia nessa área $15 \%$ da população Nambikwara que vivia em duas aldeias: Camararé e Serra Azul. O órgão indigenista oficial tinha como objetivo transferir para o lugar os demais coletivos estabelecidos nas terras férteis do Vale do Guaporé.

Ainda segundo o relatório supracitado, após ter sido demarcada a Reserva Nambikwara, a recém-instituída FUNAI deu início ao processo de concessão e emissão de certidões negativas, que tinham como objetivo principal legitimar, fraudulentamente, a não existência de indígenas no Vale do Guaporé. A esse respeito, Costa (2002) explica que em relatório produzido em 1955 pelo Departamento de Terras, Minas e Colonização, consta que as terras circunscritas ao estado de Mato Grosso se encontravam divididas em lotes e entregues a 22 companhias, sendo que cada uma delas tinha direito de ocupar, no mínimo, 200.000 hectares.

Fernandes da Silva (1987), por sua vez, comenta que no ano de 1979, o então padre jesuíta lasi denunciou que a reserva indígena criada no Vale do Guaporé estava a ser totalmente invadida por empreendimentos agropecuários; a maioria contava com financiamento da SUDAM. A autora ressalta que a liberação de incentivos por parte do órgão governamental somente era feita mediante apresentação de certidões negativas, emitidas pela FUNAI. 
Figura 2 - Foto de certidão negativa emitida pela FUNAI em 1973.

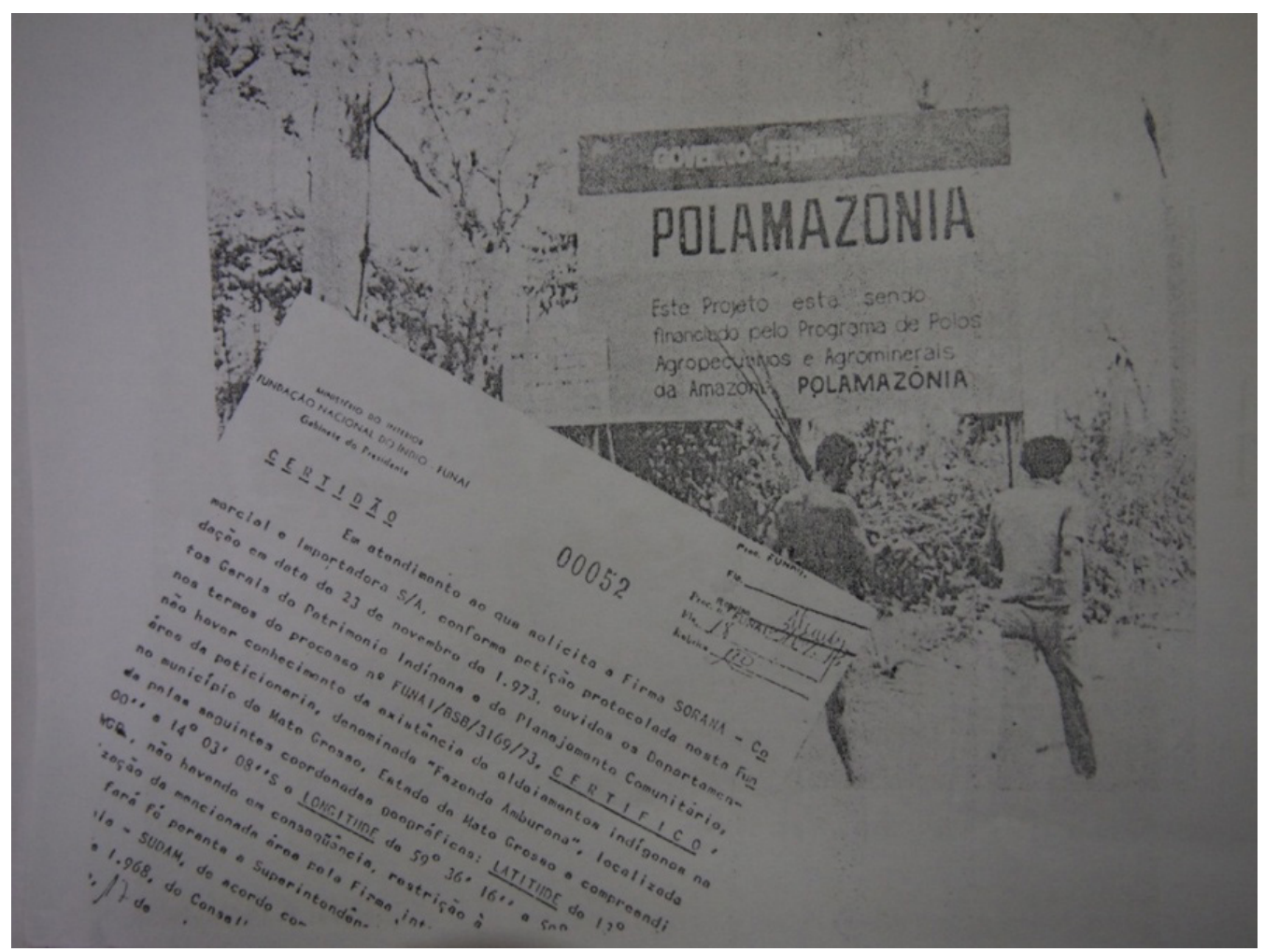

Fonte: Carelli e Severiano (1980).

Na obra Mão branca contra o povo cinza, Carelli e Severiano (1980) discorrem sobre as certidões negativas e a transferência dos indígenas do vale para a reserva recém-criada na Chapada dos Parecis.

Apenas 9 dias depois da criação da reserva, a FUNAI dá início a distribuição de certidões negativas atestando que não havia índios no Vale, documentos necessários para que empresas daqui e do mundo viessem engordar na terra Nambikwara, instaladas com dinheiro público, através dos chamados incentivos fiscais da SUDAM (Superintendência para o Desenvolvimento da Amazônia). Nas certidões, a FUNAI ainda se comprometia com os fazendeiros a transferir o povo de Etreka para a chapada inóspita, do outro lado da BR-364 (CARELLI e SEVERIANO, 1980, p.11).

Carelli e Severiano (1980) e Fernandes da Silva (1987) esclarecem que quando o coronel Costa Cavalcanti tomou posse e assumiu o Ministério do Interior, 
ocasião em que outro militar, o general Bandeira de Melo, assumia a FUNAI, o próprio filho do ministro seria um dos beneficiários de terras tituladas pelo governo de Mato Grosso na região ${ }^{5}$. Ele teria atuado no grupo Sapé, conforme pode ser observado no quadro apresentado na sequência. Nos anos de 1970 e 1971, praticamente todo o vale estava tomado por fazendas ligadas a atividades agropecuária, especialmente a criação de bovinos.

No final da década de 1960 e meados dos anos 1970, as terras em que se localizava o território do Vale do Guaporé, reconhecidamente a de solo mais fecundo de todo território Nambikwara, estavam sendo negociadas e entregues a empresários do ramo agropastoril, os quais foram beneficiados por aportes advindos de recursos federais destinados à SUDAM (COSTA, 2002).

Quadro 1 - Fazendas criadas na região do Vale do Guaporé.

\begin{tabular}{ll}
\hline FAZENDAS & ANO \\
\hline 1- Colonizadora Guaporé & 1968 \\
2- Estrela do Guaporé Florêncio Bonito S/A & 1968 \\
3- Nomura Agropecuária & 1968 \\
4- Vale do Guaporé & 1969 \\
5- Sapé Agropecuária S/A & 1969 \\
6- Leo Maniero & 1970 \\
7- Kanaxuê & 1970 \\
8- Agrário Agropecuária do Rio S/A & 1970 \\
9- Banguá S/A & 1970 \\
10- Galera S/A & 1970 \\
11- Cabixi & 1970 \\
12- Companhia Guaporé-RO & 1971 \\
13- Cerro azul & 1971 \\
14- Agropecuária União S/A & 1971 \\
15- Guaporé Galera S/A & 1971 \\
16- Nambikwara Ltda. & 1971 \\
17- Itapicuro S/A & 1971 \\
18- Edmundo José Rodrigues & 1971 \\
19- Albino Villa & 1974 \\
20- Sorano S/A & 1974 \\
21- Coonfap - Cia Nova Fronteira & 1976 \\
22- Coonfap - Cia Nova Fronteira & 1979 \\
\hline
\end{tabular}

Fonte: Carelli e Severiano (1980).

5 À época, o Ministério do Interior detinha a pasta da FUNAI. Atualmente, o órgão indigenista está ligado ao Ministério da Justiça. 
A pista de pouso retratada mais adiante, na Figura 3, foi estabelecida nos anos 1970, época em que Eduardo, missionário evangélico do Summer Institute of Linguistics (SIL), residia numa aldeia Wasusu.

Figura 3 - Pista de pouso construída na década de 1970 na aldeia da Pedra, território dos Wasusu na região do Vale do Guaporé.

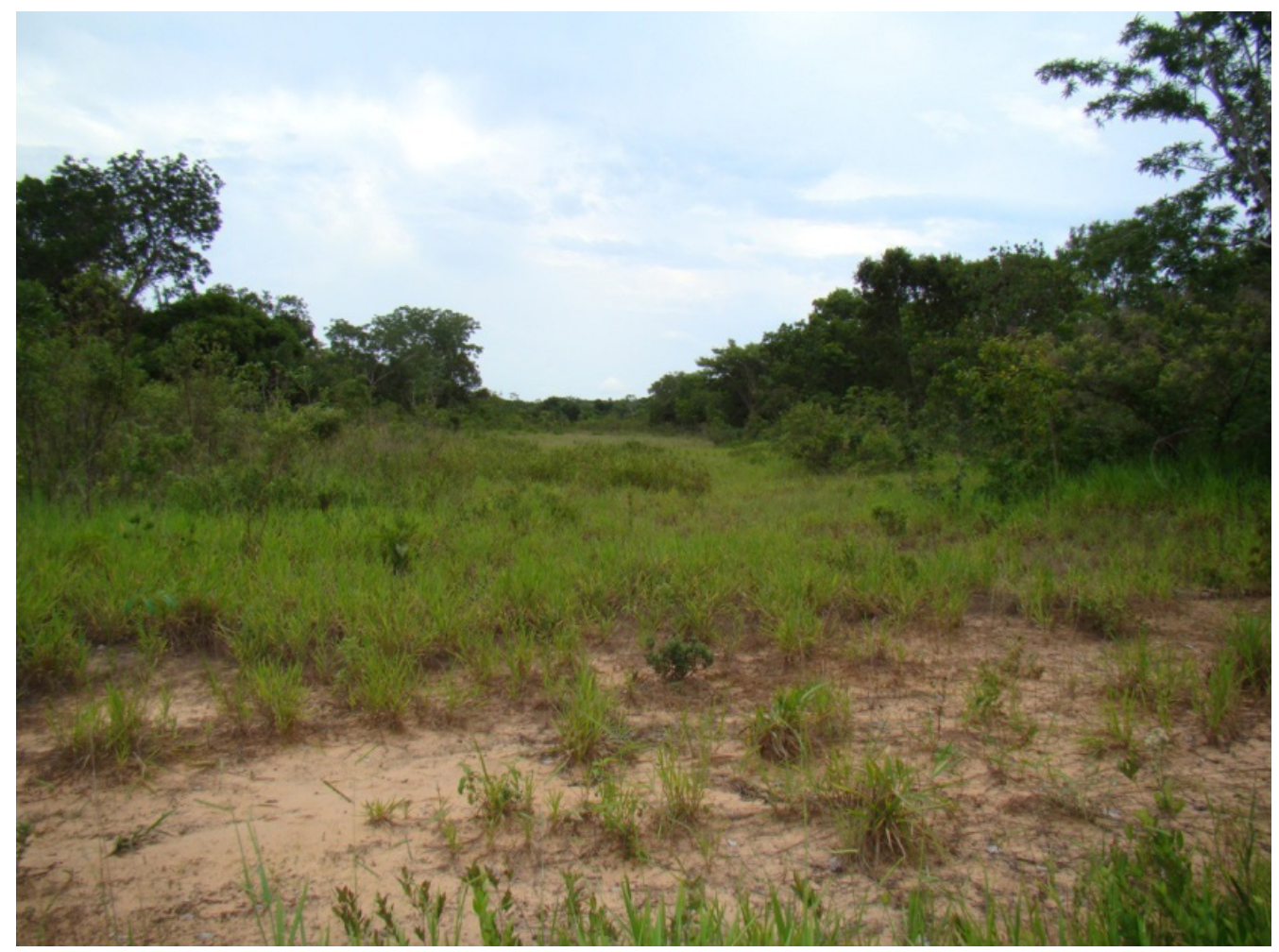

Fonte: Fotografia de Rafael Lemos de Souza, 2014.

Sobre o assunto, o ancião indígena Heru, antiga liderança Wasusu, relata que um homem desceu lá de avião e mandou que todos os índios que residiam ali se mudassem para a reserva criada na Chapada dos Parecis. Caso contrário, poderiam morrer.

Heru: Antes foi assim. O Hélio Buk [Hélio Bucker] $]^{6}$, chefe da FUNAl, veio na

6 O militar Hélio Jorge Bucker foi chefe da 6a ININD, a Inspetoria Regional vinculada ao Serviço de Proteção aos Índios. Após a extinção do SPI e criação da FUNAI, a ININD passou a ser denominada de Delegacia Regional. Bucker dedicou-se ao indigenismo oficial e foi titular da 5a . 
aldeia da Pedra, onde morávamos. Ele era bem grande, alto, feio, bravo e ruim; parece, não sei, que morava em Cuiabá. Ele veio aqui nos ameaçar; nos mandar embora de nossa terra. Ele era um homem ruim; ele falou, falou muito; ele era um mentiroso, falou que nós, os Wasusu, éramos preguiçosos, que não trabalhávamos, e que o lugar que estávamos era dos fazendeiros que iam trabalhar, derrubar as árvores e plantar muito, e que nós tínhamos que ir morar com os Nambikwara na Serra Azul, pois tínhamos que deixar as terras para os fazendeiros porque se isso não acontecesse, os fazendeiros iam nos matar; ele disse aos fazendeiros que podiam nos matar, mas aí ele falou que só era para os fazendeiros nos matar se nós mexêssemos com eles. Nesse tempo, os americanos estavam aqui. O Felipe e o Eduardo, mas o Hélio Buk mandou eles irem embora. O David Price ficou muito bravo, mas ele também era americano; ele [Hélio Bucker] mandou o David embora também; ele foi embora triste, porque não gostava do que estava acontecendo. O Hélio Buk disse: "Olha, se vocês não forem embora os fazendeiros vão pápápá, matar todo mundo". Eles tinham mesmo muitas armas, espingardas, revólveres, mas o David disse: "Vocês não podem deixar matar os índios". Hélio Buk falava muito: "Vocês índios não trabalham; são preguiçosos". Ele era um mentiroso, era tudo mentira o que ele falava; ele mentia muito. Os americanos tinham medo, não falavam nada, ficavam calados com a boca fechada dura. Eram o Eduardo e o Fritz. Ele, o Hélio Buk, voltou a falar: "Vocês vão embora ou pápápá, os fazendeiros vão matar vocês". Então, o Hélio Buk falou vocês vão embora para a Serra Azul, para a Gleba, porque aqui agora é dos fazendeiros. Hélio Buk morava em Cuiabá ou Brasília, não sei direito, mas ele era amigo desses fazendeiros, e os peões desses fazendeiros andavam muito armados. Assim ele mandou nos levar lá para o campo, para a terra dos Nambikwara, para deixar nossa floresta para os fazendeiros derrubarem, plantar roças e capim. Esse homem, o Hélio Buk, nos mandou embora de nossa terra, e mandou os americanos embora também, o Eduardo, o Fritz. Ele disse que os fazendeiros tinham muita gasolina para andar de carro e trabalhar. Mas a FUNAI era o David Price; ele disse: "Vocês não podem deixar matar os índios, não podem permitir que isso aconteça". Então o Hélio Buk disse: "Olha, peãozada, vocês não matem os índios se eles estiverem quietos, mas se eles mexerem com vocês, podem matar. Nesse caso, como estávamos em perigo de morrer matados pelos peões das fazendas, então nós fomos para a Serra Azul, conforme a FUNAl falou, e o Hélio Buk. Esse homem era bem grande, alto, barrigudo e feio. Ele, o Hélio Buk, não queria mandar só nós os Wasusu pra Serra Azul, mas todos os outros como Alantesu, Hahaitessu... Todo mundo, pra deixar

Delegacia Regional da FUNAI, no antigo estado do Mato Grosso, em 1968, conforme consta no Mapa de Conflitos Envolvendo Injustiça Ambiental e Saúde no Brasil. Disponível em: http://www. conflitoambiental.icict.fiocruz.br/index.php?pag=ficha\&cod=154. Acesso em: 12 ago. 2018. 
todas as terras para os fazendeiros. Ele, o Hélio Buk, disse que não adiantava o David Price ficar escrevendo, fazendo documento, porque ele ia mandar todos embora. Acho que ele era presidente da FUNAI, não sei. Mas ele falava, falava muito. Brigou com os americanos missionários, que disseram: "Não, nós estamos aqui por causa da Bíblia". Bíblia, diziam, que só a bíblia era verdade; Jesus eles falavam muito isso, mas era mentira, tudo era mentira dizia o Hélio Buk. Assim todos mentiam pra nós; o Hélio Buk, ele era um homem bravo e perigoso. $\mathrm{O}$ americano Eduardo quis nos defender, ele era nosso amigo. Ele falou que não podiam fazer isso com nós, que iria avisar a Polícia Federal, que a policia podia ir ver o que estava acontecendo; nós e os americanos também ficamos bravos com ele, e ele acabou indo embora triste. O Hélio Buk. Nós fomos enganados, pois quando chegamos aos Nambikwara, lá não tinha comida, não tinha caça; a gente ia caçar no mato, andava até três dias e não encontrávamos nada. A gente procurava, procurava e não encontrava porco, anta; por isso ficávamos com fome lá nas terras dos Nambikwara. Às vezes a FUNAI levava a gente pra caçar em nossas terras; nós matávamos porco bastante, mas era muita gente pra comer aí; logo toda a carne acabava e ficávamos de novo com fome. Nesse tempo, o David era a FUNAI. Aí, o Hélio Buk foi embora, então nós voltamos pra nossa terra. Aí, Silbene chegou, estava aqui com nós. Eles, o David e Silbene, fizeram documento, contando que a terra era nossa; então a Polícia Federal veio, chegou mandando toda a peãozada embora; eles foram levados de caminhão e avião; foi assim que desocupou a aldeia da Pedra, mas não dava pra nós vivermos no campo com os Nambikwara, por isso nós voltamos; aí então a FUNAI começou a nos ajudar. Isso só aconteceu porque eles viram que o Hélio Buk não gostava dos índios; nós descobrimos que o David fez muito documento. Você viu né, Rafael [Rafael Lemos de Souza], os papéis que o David fez, escreveu, né?

Rafael: Quando vocês voltaram os fazendeiros quiseram matar vocês?

Heru: Não, porque o Hélio Buk já tinha ido embora, e entrou um chefe de FUNAI melhor, que não deixava que matassem os índios. Foi assim, trocaram o chefe, porque o Hélio Buk não gostava dos índios; foi por isso que ele foi tirado da FUNAI, porque ele era ruim, só fazia mal para os índios. Por isso ele foi mandado embora, acho que ele foi pra São Paulo, ou foi embora do Brasil, outro país, né... Portugal, Peru, não sei [Heru ri porque os Wasusu saíram vitoriosos em relação ao Hélio Bucker]. O outro chefe da FUNAI que entrou era bom, comprava gasolina pro Silbene andar de carro e pra comprar outras coisas que nós precisávamos, e Silbene trazia. Assim foi desse jeito que voltamos; aí fizemos outras roças porque os fazendeiros queimaram as nossas roças antigas. Aí, nós tínhamos muita roça de novo, e muita caça, peixe; aí nós não ficamos mais com fome, porque fizemos nossas roças. (SOUZA, 2014, p. 58-9). 
A narrativa de Heru é rica em detalhes sobre a história dos Wasusu nos anos 1970. Atesta, dentre outras coisas, que a FUNAI, sob domínio dos militares, tinha o propósito e retirá-los de seu território tradicional e reassentá-los em outra área, onde não havia os recursos ambientais necessários à sua sobrevivência física e cultural. A tentativa de esbulho ou remoção forçada implica, também, em mudanças abruptas no sistema de assentamentos e na subsistência dos indígenas. Felizmente, pouco tempo depois os Wasusu conseguiram retornar à área de suas antigas aldeias, onde atividades de caça, pesca, coleta, manejo agroflorestal e agricultura poderiam ser mantidas à sua maneira.

No final do ano de 1973, precisamente na época do natal, equipes da Força Aérea Brasileira (FAB) e FUNAI tiveram que socorrer os indígenas que estavam dispersos no Vale do Guaporé, principalmente no vale do rio Sararé. Os que tinham escapado da fome estavam a morrer devido à epidemia de sarampo, doença trazida pelos "brancos" e para a qual eles não tinham grandes defesas imunológicas (CARELLI; SEVERIANO, 1980). Outras populações tinham sido afetadas por epidemias de gripe e varíola e, ainda, por doenças ocasionadas por ataques aéreos, feitos por fazendeiros ou pessoas a seu serviço que pulverizavam Tordon 155 , mais conhecido como agente laranja, sobre as aldeias. Este crime aconteceu, inclusive, nas aldeias dos Katitaurlu, também conhecidos como Nambikwara do Sararé. Sobre o assunto, assim explicam Eremites de Oliveira e Pereira:

A despeito dos desfolhantes químicos lançados por aviões e a mando de fazendeiros locais, refere-se especificamente ao Tordon 155, mais conhecido como agente laranja, usado inclusive como arma química pelos Estados Unidos na guerra contra o Vietnã, cujos efeitos são avassaladores para a saúde humana e para o meio ambiente. Em seres humanos doses elevadas de dioxina, conhecida como TCDD, um de seus componentes, tem ação teratogênica e hepatotóxica que conduz à perda de peso, lesões vasculares, úlceras gástricas, abortos espontâneos, cânceres e outros prejuízos. No meio ambiente o agente laranja serve principalmente como desfolhante químico e herbicida; destrói coberturas vegetais e com elas o habitat dos animais, acumula no solo e nos lençóis freáticos, polui toda ecologia e passa a fazer parte da cadeia alimentar [...].

Entre os Katitaurlu muitas pessoas foram envenenadas por inalação do Tordon 155 e em decorrência disso ficaram subnutridas porque, ademais, estavam com a saúde debilitada e suas roças e matas foram destruídas. Faltaram-lhes saúde e condições físicas para trabalhar em sua economia 
de subsistência, além de alimentos para colher, coletar e caçar nas matas. (EREMITES DE OLIVEIRA e PEREIRA, 2009, p. 28).

Carelli e Severiano (1980, p. 12) verificam que um médico, enviado pela Cruz Vermelha Internacional, assim teria dito em 1973: "A vida desses índios é uma vergonha não só para o Brasil, mas para a humanidade", demostrando sua indignação com o que estava a acontecer.

Figura 4 - Helicóptero da FAB a socorrer mulheres Nambikwara, enfermas devido a doenças causadas na região do Sararé, Vale do Guaporé, Mato Grosso.

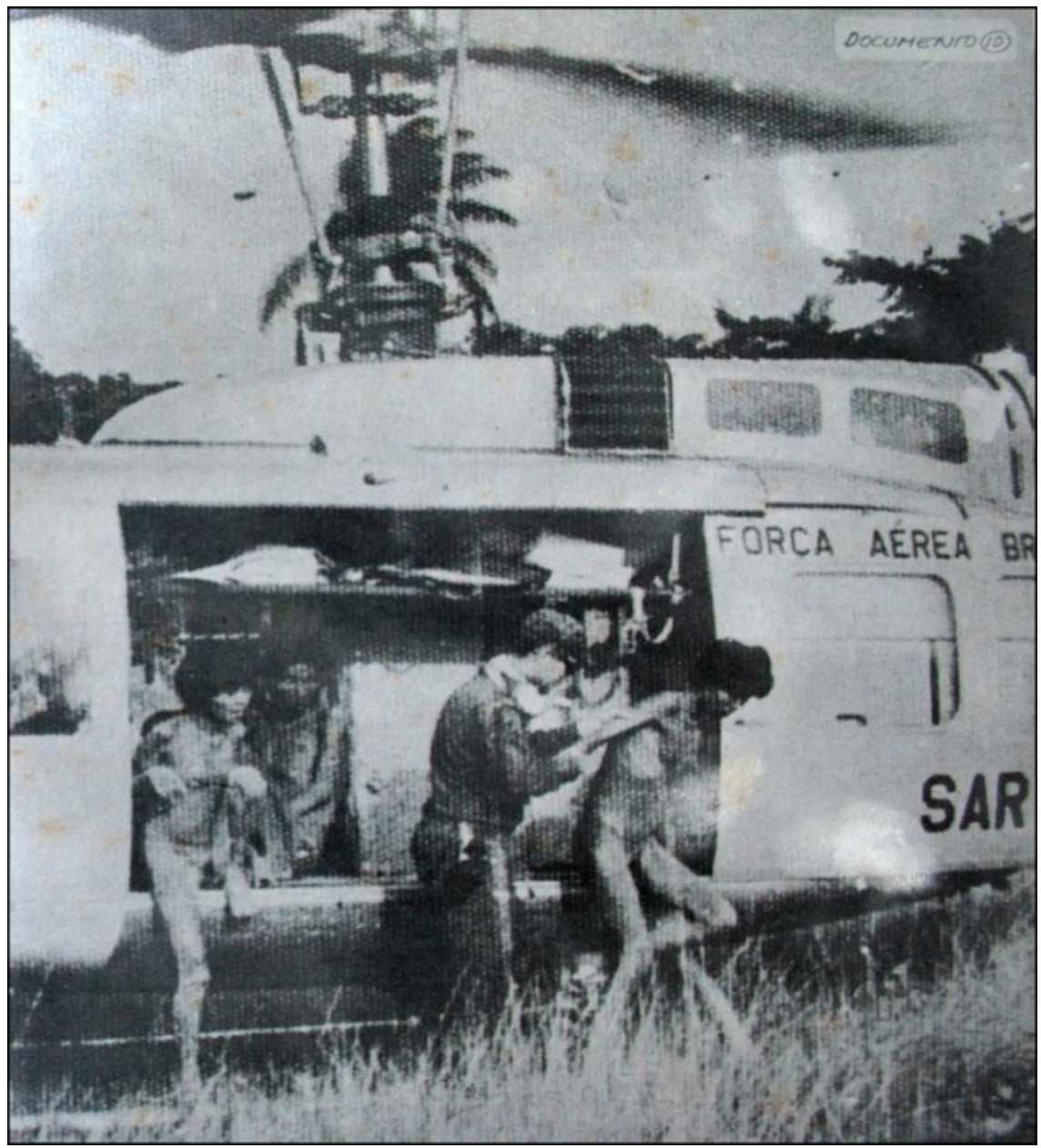

Fonte: Oliveira (1981). 
Etnoarqueologia e processo de territorialização entre os indígenas Wasusu do vale do Rio Guaporé, estado de Mato Grosso, Brasil

Figura 5 - Homem Nambikwara enfermo devido a doenças causadas na região do Sararé, Vale do Guaporé, Mato Grosso.

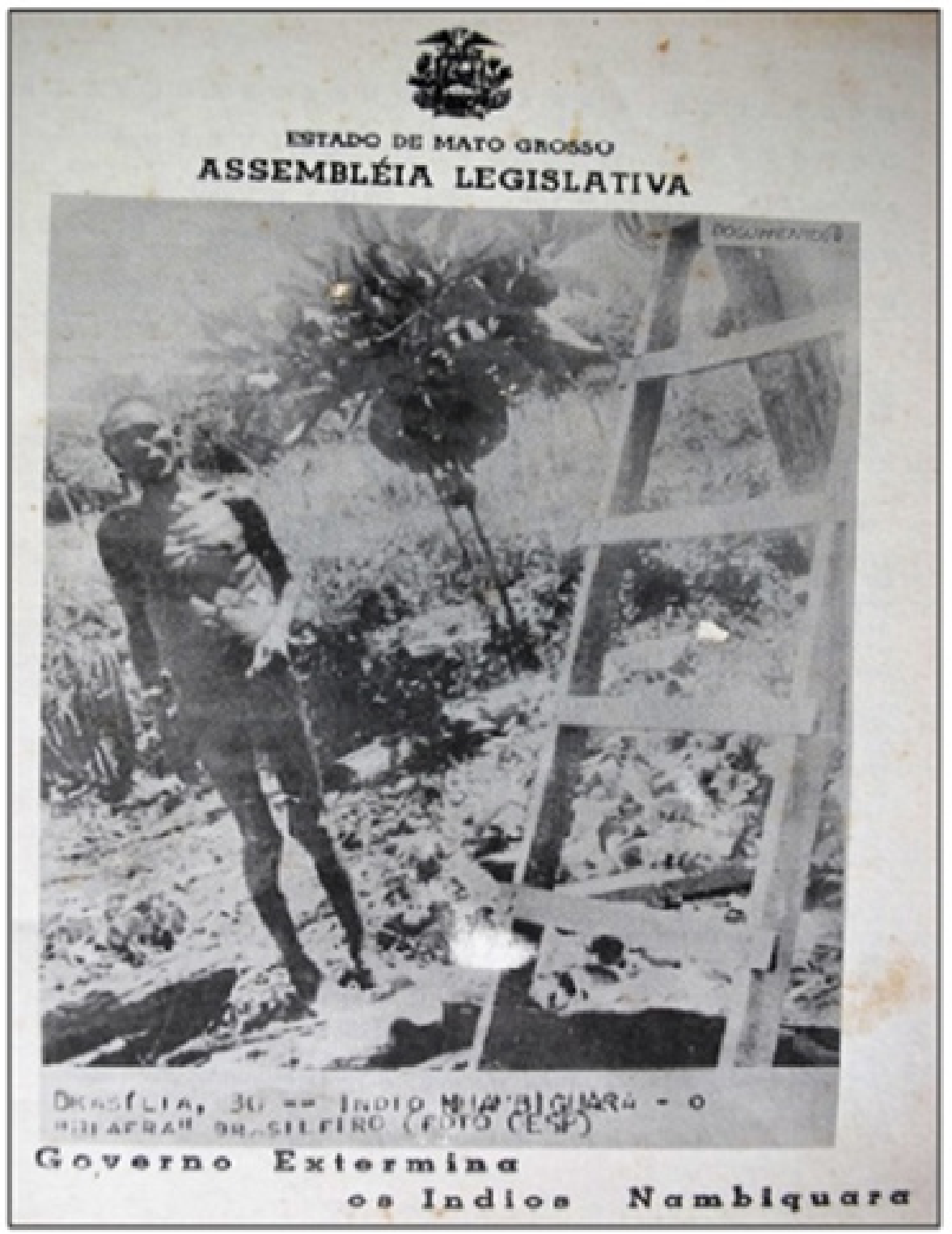

Fonte: Oliveira (1981). 
Figura 6 - Mãe e filho Nambikwara em sua casa na região do Sararé, Vale do Guaporé, Mato Groso. Na frente da residência consta uma embalagem metálica do desfolhante químico Tordon 155.

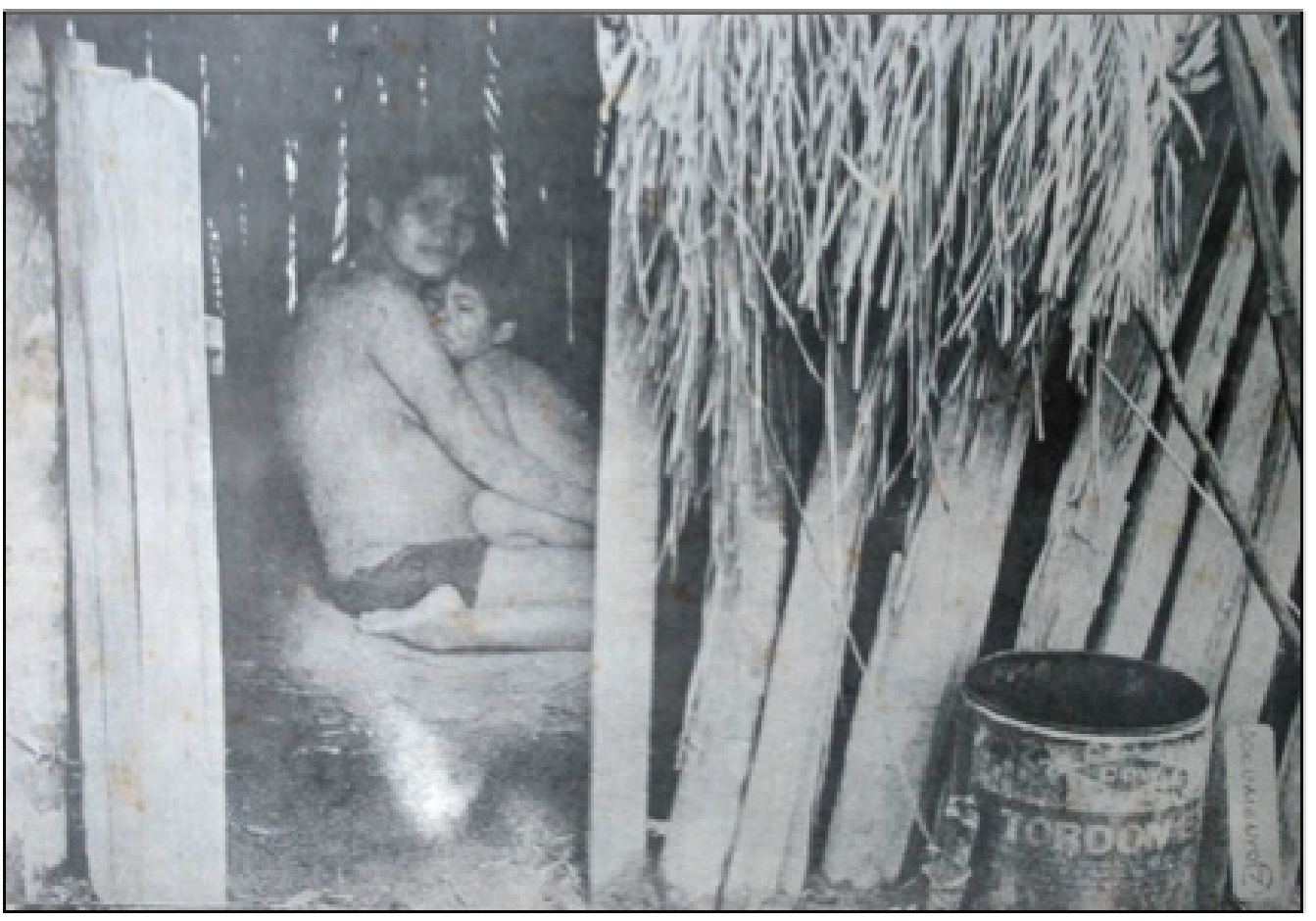

Fonte: Oliveira (1981).

A situação apontada foi assim criticada em Cuiabá, na data de 11/06/1980, pelo então deputado estadual Dante de Oliveira, durante expediente na Assembleia Legislativa do Estado de Mato Grosso:

O Governo Federal no projeto de pavimentação abandonou o traçado da BR-364 para atender os grandes grupos econômicos, interessados que o trajeto da rodovia financiada pelo Banco Mundial seja efetivado cortando o vale do Guaporé, sem se importar com a eliminação dos indígenas, com sua cultura, tradições e locais sagrados. Convém salientar que essas empresas estão ilegalmente instaladas na região atuando de forma criminosa contra o povo indígena e a natureza, utilizando indiscriminadamente o agente laranja, gerando nos seus primeiros contatos, verdadeiros escândalos, pelas doenças provocadas, caso específico da "Operação Sararé", que levou o Sr. Nelson Faria, Superintendente da SUDECO a comparar os indígenas afetados 
Etnoarqueologia e processo de territorialização entre os indígenas Wasusu do vale do Rio Guaporé, estado de Mato Grosso, Brasil

com os "exilados da Biafra".

Abandonando todas as saídas para atender aos interesses dos grandes grupos econômicos, o Governo mais uma vez demonstra que é forte apenas para reprimir trabalhadores, punir lideranças sindicais, processar deputados, mas covarde, canalha e subserviente para defender os autênticos interesses de nossa Pátria e de nosso povo. Demonstram também os homens do Governo Estadual que as "profissões de fé humanitárias" são insuficientes para mascarar a face dos verdadeiros inimigos dos índios, que a exemplo de alguns pequenos proprietários, são vítimas dos grandes latifundiários estabelecidos na Amazônia, e financiados com os incentivos fiscais custeados com o dinheiro do povo (OLIVEIRA, 1981 [1980], p.10).

Na denúncia apresentada pelo parlamentar, fica cristalina a conivência do governo federal e do governo estadual com a situação enfrentada pelos Katitaurlu e outros povos Nambikwara na região mato-grossense do Vale do Guaporé. Sem dúvida alguma, um dos maiores saldos negativos desses contatos interétnicos, iniciados com o encontro colonial e que perduram até os dias de hoje, foi a diminuição da biodiversidade e da sociodiversidade indígena na região do alto curso do rio Guaporé e adjacências.

Com todos esses problemas territoriais e epidemiológicos, também decorrentes de uma verdadeira guerra bacteriológica e química, a FUNAI resolve colocar no mesmo ano de 1973 os Mamaindê, Negarotê, Alantesu e Wasusu para cohabitarem uma reserva no bioma Cerrado. Muitos se negaram a ir e os que foram se arrependeram: "Plantamos tudo: cará, milho, mas não deu nada. A terra não presta!", disse um indígena cujo nome não foi registrado na publicação de Carelli e Severiano (1980, p.14). Até fins de 1974, os Alantesu e Wasusu voltaram para o Vale do Guaporé. No entanto, os Mamaindê e os Negarotê continuaram a morar na reserva, mas seguidamente iam caçar, pescar e cultivar seus roçados nas terras do vale, as quais estavam entregues a fazendeiros em nome do interesse "nacional". 
Figura 7- Mapa com indicação da área de transferência de povos indígenas na região do Vale do Guaporé

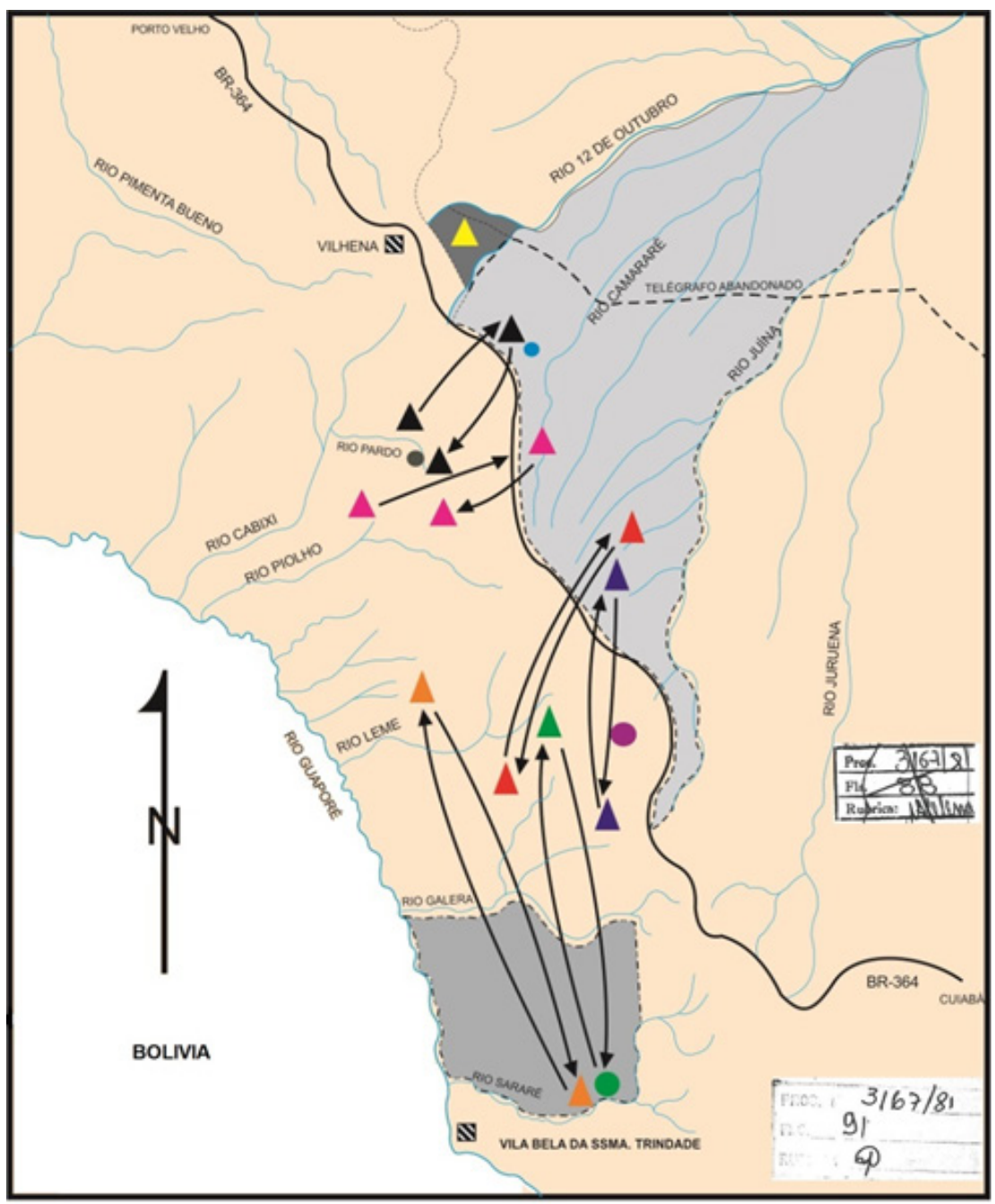

SNANS CONVENCIONAIS

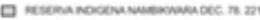

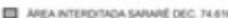

D imernoicen meneus oc soved

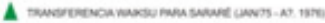

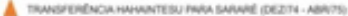

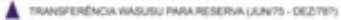

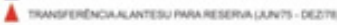

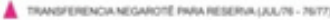

A

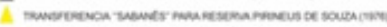

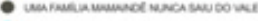

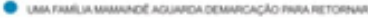

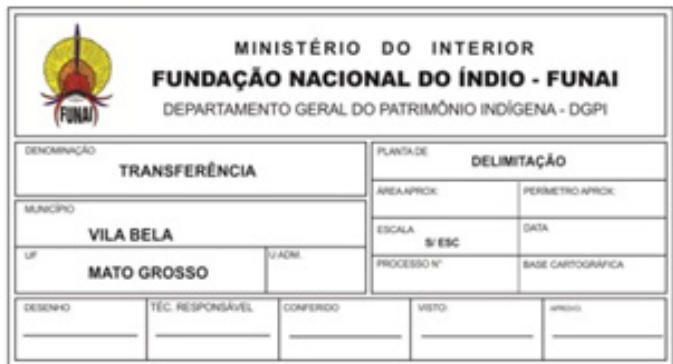

Fonte: Adaptado de FUNAI (1981). 
Após quase um ano a tentar promover a remoção forçada dos indígenas, o órgão indigenista percebe que as iniciativas de mudança não obtinham êxito. Os fracassos levaram os dois grupos - que concordaram com a mudança - a retornarem ao seu território de origem, o que ocorreu, sobremaneira, devido à baixa produtividade do solo da reserva onde foram assentados. Todavia, à época praticamente toda área do Vale do Guaporé havia sido dominada por fazendeiros com a intenção de desmatar a floresta para ali construir pastagens para a criação de bovinos.

Diante da situação, a FUNAI adotou outro expediente para alcançar seus objetivos. Arregimentou funcionários e iniciou um processo de delimitação de terras, geralmente definidas por diminutas e ilhadas reservas indígenas, assentando nelas os diversos povos indígenas ocupantes da região do Vale do Guaporé. Em outubro de 1975, o Conselho Indigenista Missionário (CIMI) aprova duas resoluções sobre o assunto: criar reserva na área interditada; paralisar o desenvolvimento das fazendas em áreas onde existissem indígenas.

Segundo consta em posterior relatório da FUNAI (1981, p.18-20), o órgão indigenista então contrata o antropólogo Pedro Agostinho da Silva, da Universidade Federal da Bahia (UFBA), para avaliar o Projeto Nambikwara. Neste documento, faz referência a outro relatório oficial, de 04/12/1975, e apresenta as seguintes observações: a) não alterar a reserva velha; b) prosseguir na tentativa de levar para a reserva velha, os índios do Norte; c) criar reserva nova na área interditada; d) realizar programas antimalárica no Vale do Guaporé; e) criar reservar Haihaintesu na região. Entretanto, a FUNAI não adotou as medidas sugeridas pelo CIMI e pelo citado antropólogo. De acordo com o mesmo relatório, no ano de 1976 o antropólogo Noraldino Vieira Cruvinel é designado para trabalhar no Vale do Guaporé, assim determinado com o propósito de indicar alternativas para solução dos problemas vivenciado pelos indígenas. São propostas pelo servidor público federal seis opções que seriam mais adequadas à população. A FUNAI decidiu pela quinta sugestão, que previa pequenas áreas independentes para os Wasusu, Alantesu e Hahaintesu, e o abandono de grande parte da terra interditada. Esta opção, segundo conta no relatório da FUNAI (1976), consiste em:

Meio lado direito da Serra São Vicente, mais parte da fazenda Sapê Sararé onde estão as aldeias do Capitão Américo e Capitão Tito, mais áreas inde- 
pendentes para Alantesu, Wasusu e Hahaintesu.

\section{Vantagens:}

a) Área suficiente para instalação de todas as aldeias, sendo que sete delas encontram-se já instaladas e uma instalação que é a dos Waysu que estão em Vila Bela;

b) Território tradicional;

c) Terras férteis, propícias à agricultura;

d) Menor atrito com fazendeiros;

e) Facilidade de acesso às aldeias;

f) Caça e pesca abundante em algumas áreas.

\section{Desvantagens:}

a) Ter que mudar três aldeias;

b) Dificuldade de assistência por parte da FUNAl, uma vez que serão necessários quatro postos de atendimento com infraestrutura e pessoal;

c) Dificuldade de contato entre as aldeias, uma vez que ficarão ilhadas entre as fazendas;

d) Dificuldade de controle do contato indiscriminado, pois que os limites são superficiais;

e) Dificuldade e impossibilidade de controle da poluição das fontes de água.

f) Dificuldade de controle da dependência das fazendas.

Durante dez anos, entre 1980 e 1990, foram demarcadas algumas áreas - ainda que de proporções geográficas modestas - de valor expressivo para os Nambikwara. Por volta de 1980, o Banco Mundial financiou o Projeto Polo Noroeste, que tinha por objetivo dar início à construção de uma estrada que unisse a rodovia federal BR-364, que liga Porto Velho a Cuiabá, passando pelo município mato-grossense de Pontes e Lacerda.

A partir da década de 1980, foi lançado o projeto Polo Noroeste, anunciado com forte entusiasmo na Revista do Interior, periódico criado na época do regime militar: "Um programa novo, bem apoiado financeiramente, se dispõe a modificar em menos de cinco anos, o panorama físico, humano e econômico do território federal de Rondônia e noroeste de Mato Grosso" (Revista do Interior, n.9, p.50). O projeto tinha como objetivo trazer o desenvolvimento econômico à moda ocidental para a região, o que se daria através da pavimentação asfáltica da rodovia BR-364 e da construção de várias estradas vicinais, além de um grande projeto de colonização para o assentamento de 22.000 famílias em Rondônia e outras 8.000 em Mato Grosso (ABREU, 2001). 
Segundo a mencionada autora, a abrangência do projeto em Mato Grosso era de $410.000 \mathrm{~km}^{2}$ e envolvia 11 municípios, os quais tinham ligação com a BR364: Cuiabá, Várzea Grande, Nossa Senhora do Livramento, Poconé, Cáceres, Mirassol do Oeste, Barra dos Bugres, Tangará da Serra, Vila Bela de Santíssima Trindade e Aripuanã, que fica na parte leste do rio Roosevelt. Ela ainda analisa que com a abertura da estrada houve o incremento do afluxo de migrantes à região, vindos das mais longínquas partes do Brasil, os quais estabeleciam fazendas e exploravam a madeira existente no território Nambikwara.

Figura 8 - Localização das Aldeias antes da construção do "novo" traçado da BR-364

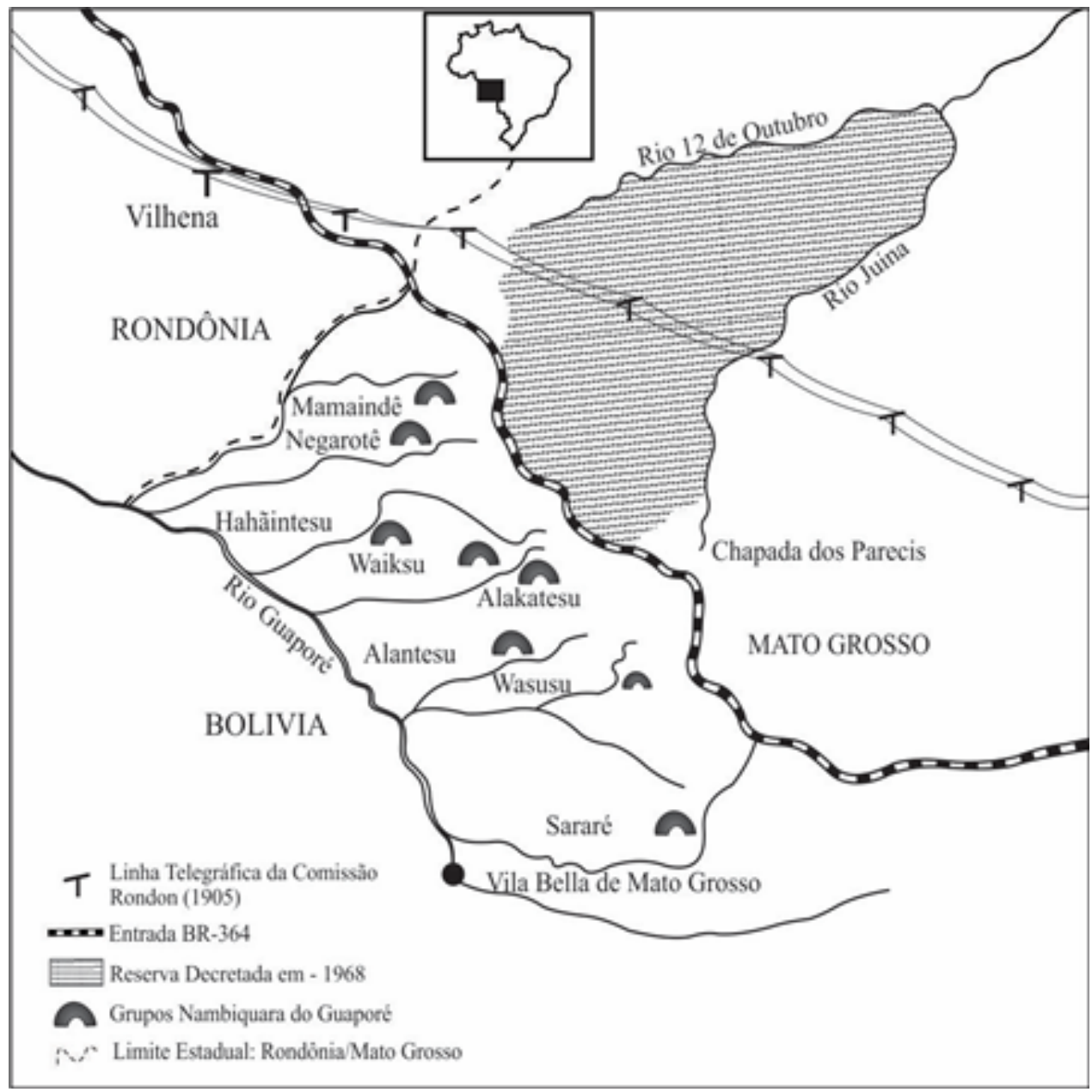

Fonte: Adaptado de Carelli e Severiano (1980). 
Figura 9 - Proposta de demarcação mínima e indispensável produzido por entidades dedicadas a defesa e proteção do índio no Brasil

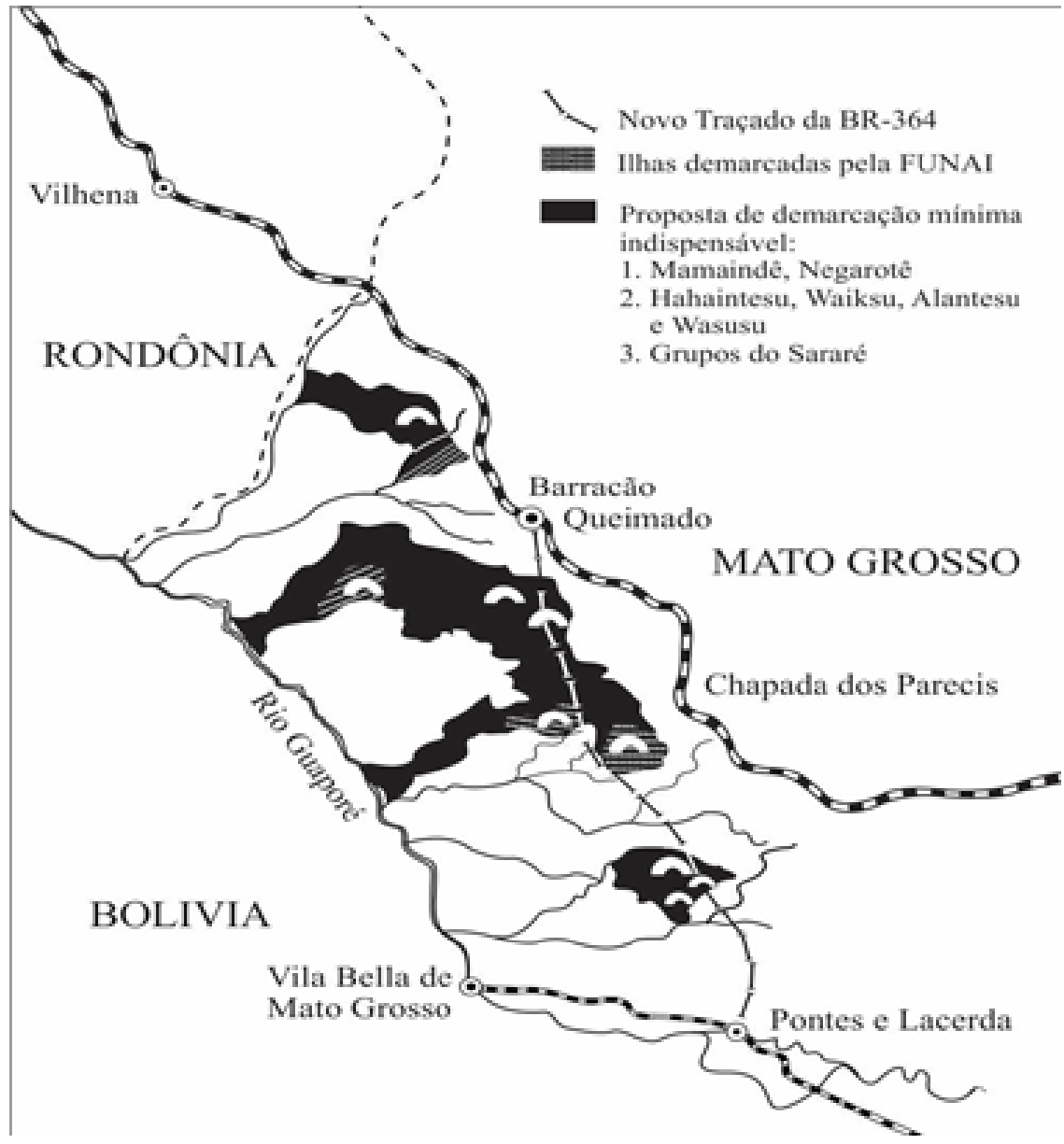

Fonte: Adaptado de Carelli e Severiano (1980).

Após esta situação, verificada especialmente durante a segunda metade do século XX, os povos Nambikwara, dentre eles os Wasusu, têm procurado viver no Vale do Guaporé à sua maneira, cada qual a partir de suas expectativas e particularidades históricas e socioculturais. Os conflitos interétnicos não cessaram totalmente naquela parte de Mato Grosso e Rondônia. Por vezes suas terras são invadidas por madeireiros, garimpeiros e outras pessoas e instituições contrárias a seus interesses, as quais tentam se apoderar das áreas tradicionalmente ocupadas e explorar os recursos ambientais ali existentes. Embora tenha sido verificada uma 
expressiva depopulação na década de 1970, posteriormente houve o crescimento populacional em várias aldeias, a exemplo daquelas onde foram realizados os estudos etnoarqueológicos que embasam o presente trabalho.

Em síntese, nota-se que durante boa parte da segunda metade do século XX, o governo de Mato Grosso e o órgão indigenista oficial, sobretudo durante o regime militar (1964-1985), atuaram juntos no sentido de promover a remoção forçada de povos Nambikwara há muito estabelecidos no Vale do Guaporé. Neste período, o SPI e depois a FUNAI agiram no sentido de beneficiar empresas colonizadoras e pessoas ligadas ao establishment da época. Exemplo disso é a concessão de certidões negativas, elaboradas de modo a atestar que em certas áreas não existiriam indígenas ou que não seriam espaços tradicionalmente ocupados por povos originários. A política indigenista oficial em vigor no período estava, portanto, direcionada à criação de uma reserva em uma área de Cerrado para ali confinar diversos coletivos Nambikwara. Esta situação favoreceu ao acirramento de conflitos internos, inclusive disputas por nichos onde havia poucos animais para a caça.

Esses contatos interétnicos provocaram, ainda, a morte de várias pessoas devido a ação de agentes patogênicos de além-mar e por conta de uma verdadeira guerra química registrada nos anos 1970. Percebe-se, assim, quão problemáticos podem ser os contatos assimétricos entre os povos indígenas e a sociedade envolvente no Vale do Guaporé, podendo desencadear uma série de intrincadas inter-relações, nem sempre pautadas pela cordialidade, tolerância e compreensão das diferenças socioculturais. Conflitos desse tipo acabaram por desencadear cisões internas entre os Wasusu: até o segundo quartel do século XX, as famílias viviam em uma grande unidade de ocupação, chamada Aldeia da Pedra; atualmente, porém, vivem distribuídas em outras três aldeias.

Nos últimos anos, das décadas de 1980 e 1990 em diante, os Wasusu têm se mobilizado politicamente para exigir seus direitos junto ao Estado nacional. Exemplo disso são casas de madeiras construídas por um consórcio da linha de transmissão que passa na área da TI Vale do Guaporé, empreendimento que provocou uma série de impactos negativos de ordem socioambiental. Carros, motocicletas e caminhonetes também foram adquiridas para serem distribuídas entre as aldeias, o que foi feito como medida compensatória a impactos gerados 
pela construção de uma PCH (Pequena Central Hidrelétrica), localizada próxima da área.

Apesar de neste artigo não ter sido abordada especificamente a materialidade dos Wasusu, faz-se necessário enfatizar que o processo de territorialização que este povo indígena sofreu não significou aculturação ou assimilação. Eles seguem com suas práticas tradicionais como parte de uma estratégia de resistência particular e, ainda, como forma de manutenção de um modo de vida singular e antiguíssimo. Arcos, flechas, balaios, colares e outros artefatos tradicionais são sistematicamente produzidos e utilizados na comunidade. No âmbito dos contatos e da dinâmica sociocultural, verificou-se a utilização de utensílios industrializados para uso cotidiano na comunidade, como panelas de alumínio, machados com lâminas de aço, recipientes plásticos para armazenar e beber água etc. Fez-se ainda a espacialização das antigas e novas aldeias e o registro e descrição de assentamentos, atividades econômicas de subsistência e cultura material em geral (ver SOUZA, 2014, p. 67-134). O mesmo tipo de continuidade e mudança da cultura material é observada em diversos estudos etnoarqueológicos, o que não implica em perda da indianidade, isto é, da distintividade étnica ou alteridade em relação à sociedade nacional envolvente.

Por fim, o importa aqui registrar que não basta ao etnoarqueólogo ir à campo para saber como os indígenas vivem e lá querer apenas observar elementos de um passado arqueológico longínquo e imemorial. É preponderante conhecer o processo de territorialização que historicamente marca seu modo de vida para compreender a materialidade das relações sociais observadas no tempo presente.

\section{REFERÊNCIAS}

ABREU, Silvana de. Planejamento governamental: a SUDECO no "Espaço mato-grossense". Contexto, propósitos e contradições. Orientadora: Ana Maria Marques Camargo Marangoni. 2001. Tese (Doutorado em Geografia) - Universidade de São Paulo, São Paulo, 2001.

CARDOSO DE OLIVEIRA, Roberto. O trabalho do antropólogo. São Paulo: Unesp, 2006.

CARELLI, Vincent; SEVERIANO, Milton. Mão branca contra o povo cinza: vamos matar este índio? São Paulo: Brasil Debates, 1980. 
Etnoarqueologia e processo de territorialização entre os indígenas Wasusu do vale do Rio Guaporé, estado de Mato Grosso, Brasil

COSTA, Ana Maria F. M. da. Senhores da memória: uma história do Nambikwara do Cerrado. Cuiabá: UNICEN/UNESCO, 2002.

EREMITES DE OLIVEIRA, Jorge. Etnoarqueologia, colonialismo, patrimônio arqueológico e cemitérios Kaiowá no estado de Mato Grosso do Sul, Brasil. Revista de Arqueologia, São Paulo, v. 29, n. 1, p. 136-69, 2016.

EREMITES DE OLIVEIRA, Jorge. Arqueologia de contrato, colonialismo interno e povos indígenas no Brasil. Amazônica: Revista de Antropologia, Belém, v. 7, n. 2, p. 354-74, 2015 a.

EREMITES DE OLIVEIRA, Jorge. (Re)aproximando os campos da antropologia social e da arqueologia no Brasil: etnoarqueologia em laudos antropológicos judiciais sobre terras indígenas em Mato Grosso do Sul. In: PACHECO DE OLIVEIRA, João; MURA, Fabio; SILVA, Alexandra B. (Org.). Laudos antropológicos em perspectiva. Brasília: ABA, 2015b. p. 234-61.

EREMITES DE OLIVEIRA, Jorge. Sistema de assentamento e processo de territorialização entre os Terena da terra indígena, Mato Grosso do Sul, Brasil. Habitus, Goiânia, v. 9, n. 1, p. 169-99, 2011.

EREMITES DE OLIVEIRA, Jorge; PEREIRA, Levi M. Reconhecimento de territórios indígenas e quilombolas em Mato Grosso do Sul: desafios para a antropologia social e a arqueologia em ambientes colonialistas. In: SIMAS DE AGUIAR, Rodrigo Luis; EREMITES DE OLIVEIRA, Jorge; PEREIRA, Levi Marques (Org.). Arqueologia, etnologia e etno-história em Iberoamerica: fronteiras, cosmología, antropología em aplicação. Dourados: Editora UFGD, 2010.

EREMITES DE OLIVEIRA, Jorge; PEREIRA, Levi M. Relatório antropológico complementar dos impactos socioambientais do Projeto São Francisco, atual Serra da Borda Mineração e Metalurgia, sobre os Katitaurlu das terras indígenas Sararé e Paukalirajausu, em Mato Grosso. Dourados: [s.n.], 2009.

FERNANDES DA SILVA, Joana Aparecida. Índios em Mato Grosso. Cuiabá: OPAN/CIMI/ Gráfica Cuiabá, 1987.

GEERTZ, Clifford. Obras e vidas: o antropólogo como autor. Rio de Janeiro: UFRJ, 2005.

GEERTZ, Clifford. A interpretação das Culturas. São Paulo: LTC, 1989.

GONZÁLEZ CASANOVA, Pablo. Exploração, colonialismo e luta pela democracia na América Latina. Prefácio de Marcos Roitman Rosenmann. Petrópolis: Vozes, 2002. 
GONZÁLEZ CASANOVA, Pablo. Colonialismo interno (uma redefinição). In: BARON, Atílio A.; AMADEO, Javier; GONZÁLEZ, Sabrina (Comp.). A teoria marxista hoje: problemas e perspectivas. São Paulo, 2007. p. 431-58.

GONZÁLEZ RUIBAL, Alfredo. El giro poscolonial: hacia una etnoarqueología crítica. Barcelona: Departament d'Arqueologia i Antropologia de la Institució Milà i FontanalsCSI, 2006.

MALINOWSKI, Bronislaw K. Magia, ciencia y religión y otros ensayos. Barcelona: PlanetaAgostini, 1984 [1948].

MALINOWSKI, Bronislaw K. Argonautas do pacifico ocidental. Tradução Eunice Ribeiro Durhan. São Paulo: Abril Cultural, 1978 [1922].

MARTINS, Olímpio Beleza. A posse e a propriedade da terra e os conflitos no oeste matogrossense. [s.l.]: [s.n], 2009. Disponível em: <http://observatoriogeograficoamericalatina. org.mx/egal3/Geografiasocioeconomica/Geografiaagraria/03.pdf>. Acesso em: $28 \mathrm{dez}$. 2011.

MILLER, Eurico Theófilo; KERN, Arno Alvarez. História da cultura indígena do Alto-Médio Guaporé (Rondônia e Mato Grosso). 1983. Dissertação (Mestrado em História) - Pontifícia Universidade Católica do Rio Grande do Sul, Porto Alegre, 1983.

MILLER, Joana. As coisas: os enfeites corporais e a noção de pessoa entre os Mamaindê (Nambikwara). 2007. Tese (Doutorado em Antropologia Social) - Universidade Federal do Rio de Janeiro, Museu Nacional, 2007.

OLIVEIRA, Dante de. Governo extermina os índios Nambiquara. Cuiabá: Assembleia Legislativa do Estado de Mato Grosso, 1981.

PACHECO DE OLIVEIRA, João. Uma etnologia dos "índios misturados"? Situação colonial, territorialização e fluxos culturais. Mana, Rio de Janeiro, v. 4, n. 1, p. 47-77, 1998.

PELS, Peter. The Anthropology of Colonialism: Culture, History, and the Emergence of Western Governmentality. Annual Review of Anthropology, v. 26, p. 163-83, 1997.

PRICE, Paul David. Nambikwara Society. 1972. Tese (Philosophy Doctor in Anthropology) - Faculty of the Division of the Social Sciences. Chicago, Illinois, 1972.

PRICE, Paul David. Política indigenista e política indígena entre os Nambiquara. Informativo FUNAI, Cuiabá, p.49-62, 1976 
Etnoarqueologia e processo de territorialização entre os indígenas Wasusu do vale do Rio Guaporé, estado de Mato Grosso, Brasil

PRICE, Paul David. Before the Bulldozer: the Nambikwara Indians and the World Bank. Washington: Seven Locks Press, 1989.

RIBEIRO, Fernanda B. Etnografias a jato. In: $\mathrm{SCHUCH}$, Patrice et al. (Org.). Experiências, dilemas e desafios do fazer etnográfico contemporâneo. Porto Alegre: Editora UFRGS, 2010. p. 85-8.

ROQUETTE-PINTO, Edgard. Rondônia. 6. ed. São Paulo: Editora Nacional, 1975 [1917].

SILVA, Fabiola Andréa. A etnoarqueologia na Amazônia: contribuições e perspectivas. Boletim do Museu Paraense Emílio Goeldi - Ciências Humanas, v. 4, n. 1, p. 27-37, 2009a.

SILVA, Fabiola Andréa. Etnoarqueologia: uma perspectiva arqueológica para o estudo da cultura material. Métis: História \& Cultura, Caxias do sul, v. 8, n. 16, p. 121-39, jul./dez. 2009b.

SILVA, Fabiola Andréa. As tecnologias e seus significados: um estudo da cerâmica dos Assurini do Xingu e das cestarias dos Kaiapó-Xinkrin sob uma perspectiva etnoarqueológica. Orientador: Lux Boelitz Vidal. 2000. Tese (Doutorado em Antropologia) - Universidade de São Paulo, São Paulo, 2000.

SILVA, Fabiola Andréa; BESPALEZ, Eduardo; STUCHI, Francisco F. Arqueologia colaborativa na Amazônia: Terra Indígena Kuatinemu, Rio Xingu, Pará. Amazônica: Revista de Antropologia, v. 3, n. 1, p. 32-59, 2011.

SILVA, Maria Aurora da. O povo da flauta: etnografia do povo Wasusu (MT) através de um olhar indigenista (1976-2010). 2010. Monografia (Graduação em Antropologia) - Pontifícia Universidade Católica de Goiás, Goiânia, GO, 2010.

SOUZA, Rafael L. de. Etnoarqueologia e história Wasusu no Vale do Rio Guaporé, Mato Grosso. 2014. Dissertação (Mestrado em Antropologia) - Universidade Federal da Grande Dourados, Dourados, MS, 2014.

STUCHI, Francisco F. A ocupação da terra indígena Kaiabi: história indígena e etnoarqueologia. Orientadora: Fabiola Andrea Silva, 2010. Dissertação (Mestrado em Arqueologia) - Museu de Arqueologia e Etnologia, Universidade de São Paulo, São Paulo, SP, 2010.

\section{Fontes Documentais}

FUNDAÇÃO NACIONAL DO ÍNDIO (FUNAI). Processo n. 3.545/1976. Relatório de viagem ao Vale do Guaporé, estado do Mato Grosso, com o fim de fazer proposições para solução do problema de terra para os Nambiquara do referido vale. 
FUNDAÇÃO NACIONAL DO ÍNDIO (FUNAI). Processo n. 3.167/1981. Relatório de viagem às áreas Nambikwara do Vale do Guaporé-MT.

MAPA de Conflitos Envolvendo Injustiça Ambiental e Saúde no Brasil. Rio de Janeiro: FIOCRUZ, 2010. Disponível em: http://www.conflitoambiental.icict.fiocruz.br/index. php?pag=ficha\&cod=154. Acesso em: 12 ago. 2018.

REVISTA DO INTERIOR, Cuiabá, n. 9, 1981 [1980].

\section{Sobre os autores:}

Rafael Lemos de Souza - Doutorando em Arqueologia pelo Museu Nacional, vinculado à Universidade Federal do Rio de Janeiro (MN/UFRJ). Mestrado em Antropologia Sócio-Cultural pela Universidade Federal de Grande Dourados (UFGD). Graduação em Arqueologia pela Pontifícia Universidade Católica de Goiás (PUC-GO). Técnico do Laboratório de Arqueologia do Museu Antropológico da Universidade Federal de Goiás (LabArq-MA/UFG). Sócio efetivo da Sociedade de Arqueologia Brasileira (SAB) e sócio pós-graduando da Associação Brasileira de Antropologia (ABA). Experiência na área de Arqueologia, com ênfase em Etnoarqueologia, Etnologia Indígena, Bioarqueologia, Zooarqueologia, Tecnologia Cerâmica, Arqueologia Histórica, Arqueologia Pré-Colonial, e Arqueologia do Pantanal. E-mail: rafaellemos@ufg.br

Jorge Eremites de Oliveira - Mestre e doutor em História/Arqueologia pela Pontifícia Universidade Católica do Rio Grande do Sul (PUCRS). Licenciado em História pela Universidade Federal de Mato Grosso do Sul (UFMS). Docente na Universidade Federal de Pelotas (UFPel), no curso de graduação e no Programa de Pós-Graduação em Antropologia, ambos articulados nos campos da Antropologia Social e Cultural e da Arqueologia. Atua, também, no Programa de Pós-Graduação em Memória Social e Patrimônio Cultural. Bolsista de produtividade em pesquisa, nível 1D, do Conselho Nacional de Desenvolvimento Científico e Tecnológico (CNPq). Tem experiências nos campos da Arqueologia, Antropologia Social e História, com ênfase em Etnoarqueologia, Etnologia Indígena e Etno-história, bem como na produção de laudos administrativos e judiciais sobre terras tradicionalmente ocupadas por comunidades indígenas. E-mail: eremites@hotmail.com

Recebido em 16 de agosto de 2018

Aprovado para publicação em 22 de novembro de 2018 